\title{
Sorafenib Acts through VEGFR-2 Inhibition in a Metastatic Clear-Cell Sarcoma of the Kidney
}

\author{
Tu V. Dao',2,3,4, Thuan V. Tran ${ }^{3,4}$, Christophe Lebœuf 1,2 , Morad El-Bouchtaoui ${ }^{1,2}$, \\ Jérôme Verine ${ }^{1,2,5}$, Anne Janin 1,2,5*, Guilhem Bousquet1,2,6,7* \\ ${ }^{1}$ Sorbonne Paris Cité, Laboratoire de Pathologie, Université Paris Diderot, Paris, France \\ ${ }^{2}$ INSERM, Paris, France \\ ${ }^{3}$ Medical Oncology Department, National Cancer Hospital, Ha Noi, Viet Nam \\ ${ }^{4}$ Oncology Department, Ha Noi Medical University, Ha Noi, Viet Nam \\ ${ }^{5}$ Laboratoire de Pathologie, AP-HP-Hôpital Saint-Louis, Paris, France \\ ${ }^{6}$ Service d'Oncologie, AP-HP-Hôpital Avicenne, Bobigny, France \\ ${ }^{7}$ Léonard de Vinci, Université Paris 13, Villetaneuse, France \\ Email: "guilhem.bousquet@aphp.fr, "anne.janin1165@gmail.com
}

Received 7 June 2016; accepted 2 July 2016; published 5 July 2016

Copyright (C) 2016 by authors and Scientific Research Publishing Inc.

This work is licensed under the Creative Commons Attribution International License (CC BY).

http://creativecommons.org/licenses/by/4.0/

cc) (7) Open Access

\section{Abstract}

We report here the case of a young patient with metastatic clear-cell sarcoma of the kidney resistant to standard chemotherapy, and with complete response under sorafenib treatment. The remarkable response of her tumor to sorafenib led us to study sorafenib molecular targets in the metastatic tissue. Background: Biomarkers predicting response to anti-angiogenic tyrosine kinase inhibitors remain to be identified. Methods and Findings: In this paper, we studied the molecular targets of sorafenib in the lung metastasis of a kidney clear-cell sarcoma. In a patient with complete response under sorafenib treatment, we showed high VEGFR2 expression by tumor endothelial cells from the lung metastasis. Conclusion: The original mechanistic results that we obtained using immunostainings and quantitative RT-PCR on laser-microdissected tumor endothelial cells have a direct application in daily clinical practice: metastatic tumors with a large angiogenic component should be tested for VEGFRs expression to consider anti-angiogenic tyrosine kinase inhibitor treatments.

\section{Keywords}

Tyrosine-Kinase Inhibitor, VEGFR2, Metastases, Clear-Cell Sarcoma of the Kidney

\footnotetext{
${ }^{*}$ Corresponding authors.
}

How to cite this paper: Dao, T.V., Tran, T.V., Lebœuf, C., El-Bouchtaoui, M., Verine, J., Janin, A. and Bousquet, G. (2016) Sorafenib Acts through VEGFR-2 Inhibition in a Metastatic Clear-Cell Sarcoma of the Kidney. Journal of Cancer Therapy, 7, 487-493. http://dx.doi.org/10.4236/jct.2016.77051 


\section{Introduction}

In the last ten years, anti-angiogenic drugs have proved to be efficient in the treatment of metastatic cancers. Sorafenib and sunitinib, two tyrosine kinase inhibitors (TKIs), have been approved for daily clinical practice. Pre-clinical data show that these two drugs act through their pro-apoptotic effect on endothelial cells [1] [2]. In patients with metastatic renal cell carcinoma treated with sunitinib, dynamic imaging detects micro-vessel changes and necrosis as early as the second week of treatment [3]. However, biomarkers predicting response to anti-angiogenic TKIs remain to be identified [4].

Clinical studies have tested constitutional pharmacogenomic markers [5] [6], or tumor-linked markers in serum or tissue [7], with few generalizable results [8]. Most tissue-based analyses have been performed on primary tumors without integrating the recent concept of primary tumor heterogeneity [9] [10]. They are also performed on tumor cells [11] and not on separated tumor endothelial cells.

In this study, we showed high VEGFR2 expression by tumor endothelial cells from the lung metastasis of a kidney clear-cell sarcoma, in a patient with complete response under sorafenib treatment.

\section{Methods}

\subsection{Assessment of Microvessel Density}

We assessed microvessel density on tissue sections of the lung metastasis of the clear-cell sarcoma. An indirect immunoperoxidase method was performed on $5 \mu \mathrm{m}$-thick tissue sections, using a rabbit polyclonal anti-human anti-CD34 antibody (Sigma-Aldrich, France) as primary antibody, and an anti-rabbit OmniMap detection kit (Roche diagnostic, Meylan, France). The systematic controls used were absence of primary antibody and use of an irrelevant primary antibody of the same isotype.

For all tissue sections, the count of CD34-positive microvessels was performed using a ProvisAX70 microscope (Olympus, Tokyo) with wide-field eyepiece number 26.5, providing a field size of $0.344 \mathrm{~mm}^{2}$ at $\times 400$ magnification. Microscopic pictures were captured using a Color View III digital camera, and analyzed using Olympus-SIS Cell F software. CD34-poitive microvessels were counted on ten different fields at X400 magnification. Results were expressed as the mean \pm standard deviation.

\subsection{Double Immunofluorescence Stainings}

Double fluorescent immunostainings were performed using the following primary antibodies: a rabbit antiCD34 antibody (polyclonal human, Sigma-ald, Germany) coupled with donkey anti-rabbit IgG H\&L Alexa Fluor 555 (polyclonal rabbit, 1/200, Abcam, UK); human VEGFR1/Flt-1 and VEGF R2/KDR antibodies (monoclonal mouse, $1 / 100, \mathrm{R} \& \mathrm{D}$ Systems, USA) coupled with a donkey anti-mouse IgG H\&L Alexa Fluor 488 (polyclonal, 1/200, Abcam, France); the human PDGFR $\alpha$ and PDGFR $\beta$ antibodies (monoclonal mouse, 1/100, R\&D Systems, USA) coupled with a donkey anti-mouse IgG H\&L Alexa Flour 488 (polyclonal, 1/200, Abcam, France). Multiple fluorescence analyses were performed by two pathologists (AJ, CL) on a motorized Z-axis Olympus (Tokyo, Japan) BX 61 microscope. Microscope images obtained through a UPlan FI 100×/1.3 NA objective were captured with a ColorView III digital camera using Olympus-SIS Cell F software.

\subsection{Laser-Microdissection of Tumor Endothelial Cells}

For laser-microdissection of tumor endothelial cells, two metastatic tumor samples have been used: 1) the lung metastatic sample of our young patient with a metastatic clear cell sarcoma of the kidney; 2) a lung metastatic sample of a patient with a metastatic renal cell carcinoma treated with sunitinib and responsive to treatment. Response to sunitinib treatment was defined according to Response Evaluation Criteria in Solid Tumors [12]. After 3 months of treatment, the responder patient had a 35\% tumor response using computed tomography.

Seven-micrometer-thick paraffin sections were spread on membrane coated slides and stained with a direct immunofluorescence method. Tissue microdissection was performed with the laser microbeam microdissection system (Zeiss, Germany). A $337 \mathrm{~nm}$ UV-laser was used to catapult small tissue fragments directly into the cap of a sample tube without any mechanical contact. Endothelial cells microdissected were catapulted in separate vials containing $150 \mu \mathrm{L}$ of lysis buffer (Proteinase digest buffer from RNeasy-Mini-Kit (Quiagen, Les-Ulis, France)), then incubated for 15 minutes at $56^{\circ} \mathrm{C}$ and proteinase $\mathrm{K}$ was inactivated by heating at $80^{\circ} \mathrm{C}$ for 15 minutes. 


\subsection{Quantitative Real-Time PCR of Sorafenib Molecular Targets}

Total RNA was extracted from microdissected cells using R Neasy-Mini-Kit (Qiagen, Les-Ulis, France), quantified on NanoDrop and qualified on Bio-Rad Experion ${ }^{\mathrm{TM}}$ Automated-Electrophoresis-Station (BioRad/Marnesla-Coquette/France). Human umbilical vein endothelial cells (HUVEC) were used as calibrator. For RT-qPCR, total RNA was reverse-transcribed using random primers with SuperScript ${ }^{\mathrm{TM}}$ II-Reverse-Transcrip-tase (Invitrogen/Saint-Aubin/France). The qPCR reactions were performed using fluorescent probes on a CFX96 Real Time System (Bio-Rad, USA). Reference gene was human TBP with the primer Hs99999910_m1, a blank sample (no cDNA) was included, and experiments performed in triplicate, with each sample in duplicate on the PCR plate. The results were expressed as $-\Delta \mathrm{C}_{\mathrm{q}}$ (quantification cycle), $\Delta \mathrm{C}_{\mathrm{q}}=\mathrm{C}_{\mathrm{q}}$ (gene tested) $-\mathrm{C}_{\mathrm{q}}$ (reference gene) [13].

The following human genes were analyzed: VEGFR1 [Hs01052936_m1], VEGFR2 [Hs00176676_m1], PDGFRA [Hs00183486_m1], PDGFRB [Hs00199831_m1], and FLT3 [Hs00975659_m1].

\subsection{Case Presentation and Results}

A localized nephroblastoma of the left kidney was diagnosed in a 13-year-old Vietnamese girl. She underwent radical left nephrectomy and post-surgery chemotherapy. In accordance withthe National Wilms Tumor Study/ Child Oncology Group (NWTS/COG) protocol, she received a total of 17 weeks of vincristine plus dactinomycin. Fourteen months later, she developed a single $4.5 \mathrm{~cm}$ lung metastasis. She received vincristine, doxorubicin and cyclophosphamide, but after six weeks of treatment, the lung metastasis had progressed and was removed surgically. Three months later, the lung metastasis had grown back (Figure 1(a)-left panel), and this led us to

At beginning of sorafenib treatment

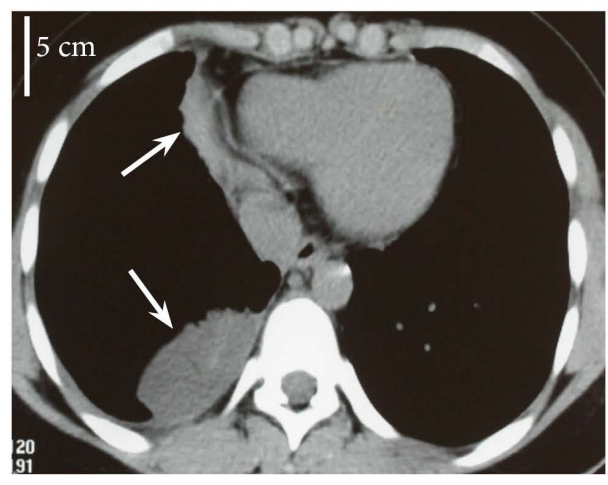

After 3 months of treatment

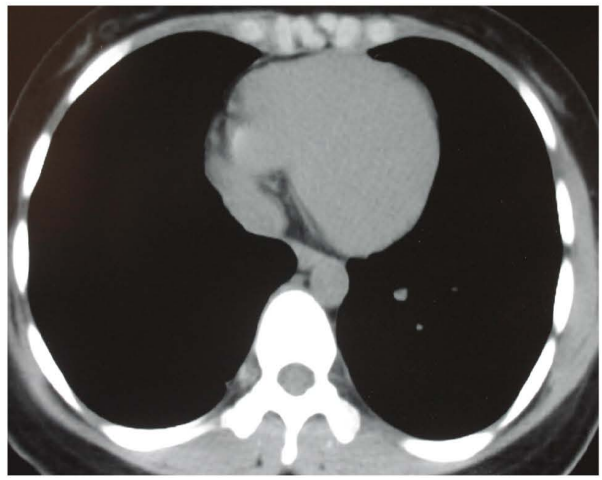

(a)

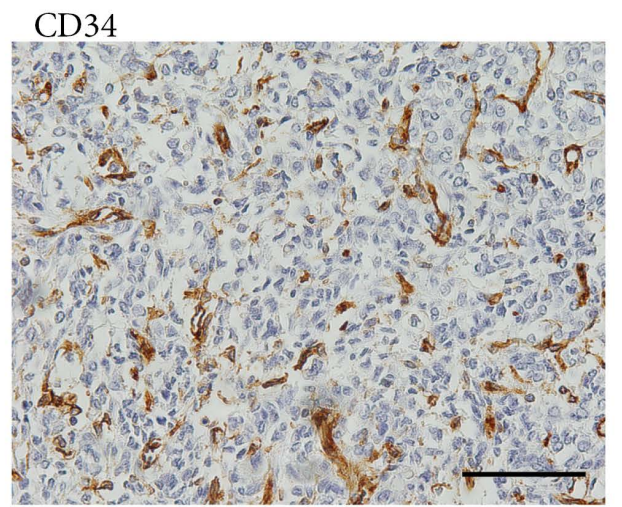

(b)

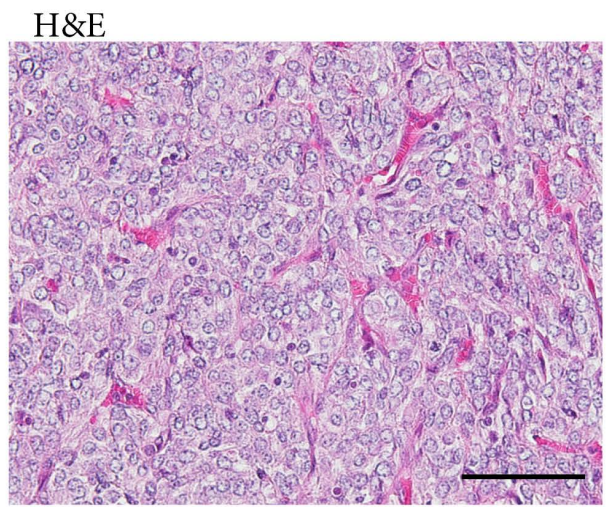

Figure 1. (a) Lung metastases (white arrows) on computed tomography at the beginning of sorafenib treatment (left panel), and their disappearance after 3 months of treatment (right panel); (b) Hematoxylin-eosin coloration shows the clear-cell sarcoma (left panel), with numerous microvessels stained with CD34 antibody (right panel). $\times 200$ magnification. 
reconsider the initial diagnosis of nephroblastoma. A second pathologist expertise (JV) concluded to clear- cell sarcoma (Figure 1(b)-left panel), with tumor cells expressing vimentin but not EMA, cytokeratin 20, protein S100 and neuron-specific enolase. The lung metastasis had a high mean vascular density of $12( \pm 4)$ CD34- expressing microvessels per field at $\times 400$ magnification (Figure 1(b)-right panel). This angiogenic characteristic of the metastasis led us to propose a treatment with sorafenib, at a daily dose of $400 \mathrm{mg}$, to avoid the toxicity observed in the Asian population at daily doses of $800 \mathrm{mg}$ [14]. After 3 months of treatment, a complete response was found on computed tomography (Figure 1(a)-right panel), and the patient had no toxicity. Now, after 18 months of sorafenib treatment, the patient is still alive without any sign of disease.

Sorafenib is currently used for the treatment of metastatic or locally advanced renal cell carcinoma, hepatocellular carcinoma, and thyroid carcinoma. For metastatic clear-cell sarcoma, cytotoxic drugs are currently used [15]. For our patient, a personalized therapeutic approach of the lung metastasis was chosen because: 1) ithad progressed in spite of two lines of chemotherapy; and 2) it was highly angiogenic. The remarkable response of her tumor to sorafenib led us to study sorafenib molecular targets in the metastatic tissue.

In preclinical studies, the main targets of sorafenib are vascular endothelial growth factor receptors (VEGFRs) and platelet-derived growth factor receptors (PDGFRs) [2].

Using multiple immunofluorescence staining on the lung metastasis of our patient (see Supplementary methods), we showed that CD34-expressing endothelial cells co-expressed VEGFR1 or VEGFR2 (Figure 2(a)), but not PDGFR $\alpha$ nor PDGFR $\beta$.

On the same metastatic sample, we laser-microdissected CD34-expressing endothelial cells (Figure 2(b)). After mRNA extraction, we assessed the expression level of the same sorafenib molecular targets using quantitative RT-PCR. We used human umbilical vein endothelial cells (HUVEC) as a positive control because they have a higher sensitivity to sorafenib, and a higher VEGFR2 protein expression than tumor endothelial cells sorted from human cancers [16] [17]. To overcome the problem of the difference between endothelial cell lines and tumor endothelial cells selected from the lung metastases using laser-microdissection, we also included in this study laser-microdissected tumor endothelial cells from lung metastases of a patient with renal cancer responsive to sunitinib treatment.

The levels of mRNA expression found in laser-microdissected tumor endothelial cells from our patient, from the metastatic control sample, and in the HUVEC were high for VEGFR2 $\left(-\Delta \mathrm{C}_{\mathrm{q}}=18.9,19.2\right.$, and 20.9 respectively). They were lower for $\operatorname{VEGFR} 1\left(-\Delta \mathrm{C}_{\mathrm{q}}=15.1,10.8\right.$, and 18.3 respectively), and even more so for $\operatorname{PDGFR} \alpha\left(-\Delta \mathrm{C}_{\mathrm{q}}=0,17.9\right.$, and 6.6, respectively), $\operatorname{PDGFR} \beta\left(-\Delta \mathrm{C}_{\mathrm{q}}=6,14.2\right.$, and12.7, respectively), and FLT3 $\left(-\Delta \mathrm{C}_{\mathrm{q}}=4.6,5\right.$ and 5.7 respectively) (Figure $\left.2(\mathrm{c})\right)$.

\section{Discussions}

The relationship we found between VEGFR2 expression by endothelial cells and response to sorafenib in our patient was not found in a previous study on primary renal cancers from 23 metastatic patients treated with sunitinib, another TKI [18]. This discrepancy could be linked to the fact that we separately analyzed tumor endothelial cells selected using laser-microdissection.

Convincing data support the idea that tumor endothelial cells sorted from human cancers are not normal endothelial cells, and that they have their own phenotype [16] [17]. Using murine xenografts from three human cancer cell lines, we have shown that sunitinib induces different apoptotic damages in endothelial and tumor cells according to the cancer cell line injected. We have also shown that the expression levels of sunitinib molecular targets enable the assessment of therapeutic response [19].

The original mechanistic results we obtained using immunostainings and RT-qPCR on laser-microdissected tumor endothelial cells have a direct application in daily clinical practice: metastatic tumors with a large angiogenic component should be tested for VEGFRs expression to consider anti-angiogenic TKI treatments.

\section{Acknowledgements}

Ms Angela Swaine reviewed the English language.

Written informed consent was obtained from the patient and her mother for the publication of this Case report and images. A copy of the written consent is available for review by the Editor-in-Chief of this journal. 

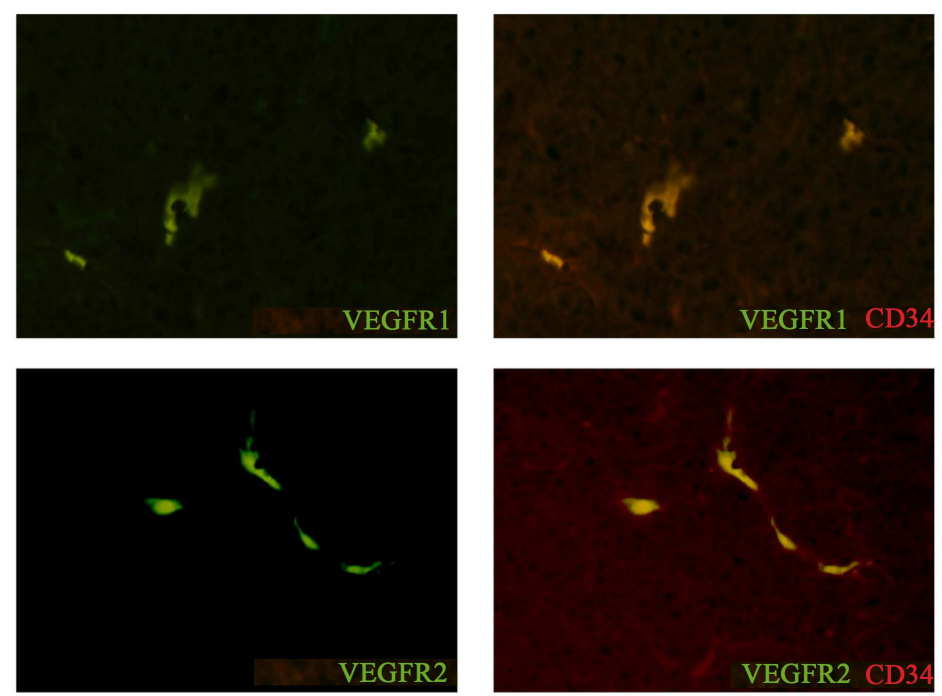

(a)
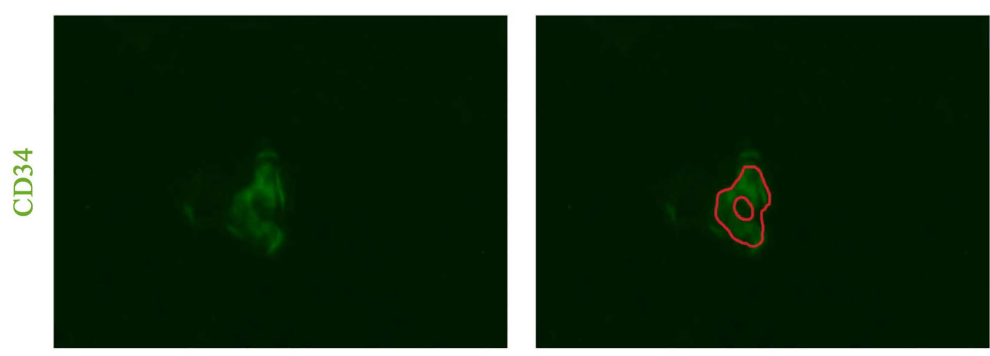

(b)

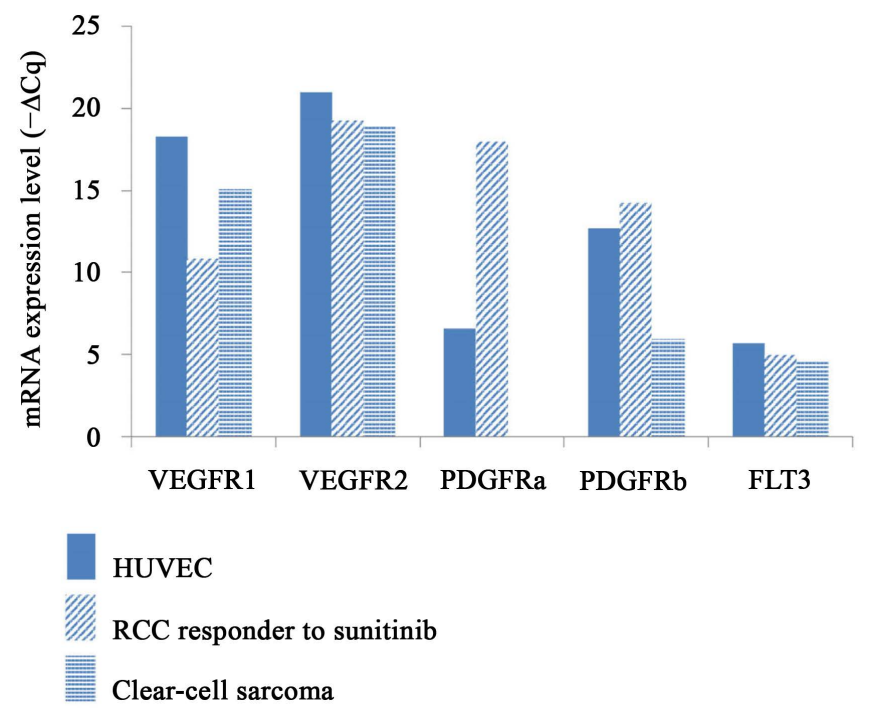

(c)

Figure 2. (a) Multiple staining on the lung metastatic sample shows a co-staining of CD34-expressing endothelial cells with VEGFR1 or VEGFR2. X200 magnification; (b) CD34-expressing tumor endothelial cells (green) are laser-microdissected to analyze them separately for mRNA expression of sorafenib molecular target. $\times 400$ magnification; (c) mRNA expression levels $\left(-\triangle \mathrm{C}_{\mathrm{a}}\right)$ of VEGFR1,VEGFR2, PDGFR $\alpha, P D G F R \beta$, and FLT-3 in three types of endothelial cells: 1) HUVEC; 2) laser-microdissected CD34-expressing tumor-endothelial cells from a lung metastasis of a patient responsive to sunitinib treatment; and 3) laser-microdissected CD34-expressing tumor-endothelial cells from the lung metastasis of our patient with a clear-cell sarcoma. 


\section{Funding}

This work was supported by University-Paris-Diderot, INSERM.

\section{Conflict of Interest}

The authors do not have any conflict of interest.

\section{References}

[1] Huang, D., Ding, Y., Li, Y., Luo, W.M., Zhang, Z.F., Snider, J., Vandenbeldt, K., Qian, C.N. and Teh, B.T. (2010) Sunitinib Acts Primarily on Tumor Endothelium Rather than Tumor Cells to Inhibit the Growth of Renal Cell Carcinoma. Cancer Research, 70, 1053-1062. http://dx.doi.org/10.1158/0008-5472.CAN-09-3722

[2] Wilhelm, S.M., Carter, C., Tang, L., Wilkie, D., McNabola, A., Rong, H., Chen, C., Zhang, X., Vincent, P., McHugh, M., Cao, Y., Shujath, J., Gawlak, S., Eveleigh, D., Rowley, B., Liu, L., Adnane, L., Lynch, M., Auclair, D., Taylor, I., Gedrich, R., Voznesensky, A., Riedl, B., Post, L.E., Bollag, G. and Trail, P.A. (2004) BAY 43-9006 Exhibits Broad Spectrum Oral Antitumor Activity and Targets the RAF/MEK/ERK Pathway and Receptor Tyrosine Kinases Involved in Tumor Progression and Angiogenesis. Cancer Research, 64, 7099-7109. http://dx.doi.org/10.1158/0008-5472.CAN-04-1443

[3] Lassau, N., Koscielny, S., Albiges, L., Chami, L., Benatsou, B., Chebil, M., Roche, A. and Escudier, B.J. (2010) Metastatic Renal Cell Carcinoma Treated with Sunitinib: Early Evaluation of Treatment Response Using Dynamic Contrast-Enhanced Ultrasonography. Clinical Cancer Research, 16, 1216-1225.

[4] Negrier, S. and Raymond, E. (2012) Antiangiogenic Treatments and Mechanisms of Action in Renal Cell Carcinoma. Investigational New Drugs, 30, 1791-1801. http://dx.doi.org/10.1007/s10637-011-9677-6

[5] Garcia-Donas, J., Esteban, E., Leandro-Garcia, L.J., Castellano, D.E., del Alba, A.G., Climent, M.A., Arranz, J.A., Gallardo, E., Puente, J., Bellmunt, J., Mellado, B., Martinez, E., Moreno, F., Font, A., Robledo, M. and RodriguezAntona, C. (2011) Single Nucleotide Polymorphism Associations with Response and Toxic Effects in Patients with Advanced Renal-Cell Carcinoma Treated with First-Line Sunitinib: A Multicentre, Observational, Prospective Study. The Lancet Oncology, 12, 1143-1150. http://dx.doi.org/10.1016/S1470-2045(11)70266-2

[6] Lee, Y.S., Kim, B.H., Kim, B.C., Shin, A., Kim, J.S., Hong, S.H., Hwang, J.A., Lee, J.A., Nam, S., Lee, S.H., Bhak, J. and Park, J.W. (2015) SLC15A2 Genomic Variation Is Associated with the Extraordinary Response of Sorafenib Treatment: Whole-Genome Analysis in Patients with Hepatocellular Carcinoma. Oncotarget, 6, 16449-16460. http://dx.doi.org/10.18632/oncotarget.3758

[7] Penel, N., Ray-Coquard, I., Bal-Mahieu, C., Chevreau, C., Le Cesne, A., Italiano, A., Bompas, E., Clisant, S., Baldeyrou, B., Lansiaux, A., Robin, Y.M., Bay, J.O., Piperno-Neumann, S., Blay, J.Y. and Fournier, C. (2014) Low Level of Baseline Circulating VEGF-A Is Associated with Better Outcome in Patients with Vascular Sarcomas Receiving Sorafenib: An Ancillary Study from a Phase II Trial. Targeted Oncology, 9, 273-277. http://dx.doi.org/10.1007/s11523-013-0299-0

[8] Garcia-Roig, M., Ortiz, N. and Lokeshwar, V. (2014) Molecular Marker for Predicting Treatment Response in Advanced Renal Cell Carcinoma: Does the Promise Fulfill Clinical Need? Current Urology Reports, 15, 375. http://dx.doi.org/10.1007/s11934-013-0375-0

[9] Gerlinger, M., Horswell, S., Larkin, J., Rowan, A.J., Salm, M.P., Varela, I., Fisher, R., McGranahan, N., Matthews, N., Santos, C.R., Martinez, P., Phillimore, B., Begum, S., Rabinowitz, A., Spencer-Dene, B., Gulati, S., Bates, P.A., Stamp, G., Pickering, L., Gore, M., Nicol, D.L., Hazell, S., Futreal, P.A., Stewart, A. and Swanton, C. (2014) Genomic Architecture and Evolution of Clear Cell Renal Cell Carcinomas Defined by Multiregion Sequencing. Nature Genetics, 46, 225-233. http://dx.doi.org/10.1038/ng.2891

[10] Bousquet, G., Bouchtaoui, M.E., Leboeuf, C., Battistella, M., Varna, M., Ferreira, I., Plassa, L.F., Hamdan, D., Bertheau, P., Feugeas, J.P., Damotte, D. and Janin, A. (2015) Tracking Sub-Clonal TP53 Mutated Tumor Cells in Human Metastatic Renal Cell Carcinoma. Oncotarget, 6, 19279-19289. http://dx.doi.org/10.18632/oncotarget.4220

[11] Horwitz, E., Stein, I., Andreozzi, M., Nemeth, J., Shoham, A., Pappo, O., Schweitzer, N., Tornillo, L., Kanarek, N., Quagliata, L., Zreik, F., Porat, R.M., Finkelstein, R., Reuter, H., Koschny, R., Ganten, T., Mogler, C., Shibolet, O., Hess, J., Breuhahn, K., Grunewald, M., Schirmacher, P., Vogel, A., Terracciano, L., Angel, P., Ben-Neriah, Y. and Pikarsky, E. (2014) Human and Mouse VEGFA-Amplified Hepatocellular Carcinomas Are Highly Sensitive to Sorafenib Treatment. Cancer Discovery, 4, 730-743. http://dx.doi.org/10.1158/2159-8290.cd-13-0782

[12] Eisenhauer, E.A., Therasse, P., Bogaerts, J., Schwartz, L.H., Sargent, D., Ford, R., Dancey, J., Arbuck, S., Gwyther, S., Mooney, M., Rubinstein, L., Shankar, L., Dodd, L., Kaplan, R., Lacombe, D. and Verweij, J. (2009) New Response Evaluation Criteria in Solid Tumours: Revised RECIST Guideline (Version 1.1). European Journal of Cancer, 45, 
228-247. http://dx.doi.org/10.1016/j.ejca.2008.10.026

[13] Bustin, S.A., Benes, V., Garson, J.A., Hellemans, J., Huggett, J., Kubista, M., Mueller, R., Nolan, T., Pfaffl, M.W., Shipley, G.L., Vandesompele, J. and Wittwer, C.T. (2009) The MIQE Guidelines: Minimum Information for Publication of Quantitative Real-Time PCR Experiments. Clinical Chemistry, 55, 611-622.

http://dx.doi.org/10.1373/clinchem.2008.112797

[14] Fukudo, M., Ito, T., Mizuno, T., Shinsako, K., Hatano, E., Uemoto, S., Kamba, T., Yamasaki, T., Ogawa, O., Seno, H., Chiba, T. and Matsubara, K. (2014) Exposure-Toxicity Relationship of Sorafenib in Japanese Patients with Renal Cell Carcinoma and Hepatocellular Carcinoma. Clinical Pharmacokinetics, 53, 185-196. http://dx.doi.org/10.1007/s40262-013-0108-Z

[15] Gooskens, S.L., Furtwangler, R., Spreafico, F., van Tinteren, H., de Kraker, J., Vujanic, G.M., Leuschner, I., CoulombL'Hermine, A., Godzinski, J., Schleiermacher, G., Stoneham, S., Bergeron, C., Pritchard-Jones, K., Graf, N. and van den Heuvel-Eibrink, M.M. (2014) Treatment and Outcome of Patients with Relapsed Clear Cell Sarcoma of the Kidney: A Combined SIOP and AIEOP Study. British Journal of Cancer, 111, 227-233. http://dx.doi.org/10.1038/bjc.2014.291

[16] Xiong, Y.Q., Sun, H.C., Zhang, W., Zhu, X.D., Zhuang, P.Y., Zhang, J.B., Wang, L., Wu, W.Z., Qin, L.X. and Tang, Z.Y. (2009) Human Hepatocellular Carcinoma Tumor-Derived Endothelial Cells Manifest Increased Angiogenesis Capability and Drug Resistance Compared with Normal Endothelial Cells. Clinical Cancer Research: An Official Journal of the American Association for Cancer Research, 15, 4838-4846. http://dx.doi.org/10.1158/1078-0432.CCR-08-2780

[17] Fiorio Pla, A., Brossa, A., Bernardini, M., Genova, T., Grolez, G., Villers, A., Leroy, X., Prevarskaya, N., Gkika, D. and Bussolati, B. (2014) Differential Sensitivity of Prostate Tumor Derived Endothelial Cells to Sorafenib and Sunitinib. BMC Cancer, 14, 939. http://dx.doi.org/10.1186/1471-2407-14-939

[18] Paule, B., Bastien, L., Deslandes, E., Cussenot, O., Podgorniak, M.P., Allory, Y., Naimi, B., Porcher, R., de La Taille, A., Menashi, S., Calvo, F. and Mourah, S. (2010) Soluble Isoforms of Vascular Endothelial Growth Factor Are Predictors of Response to Sunitinib in Metastatic Renal Cell Carcinomas. PloS One, 5, e10715. http://dx.doi.org/10.1371/journal.pone.0010715

[19] Bousquet, G., Varna, M., Ferreira, I., Wang, L., Mongiat-Artus, P., Leboeuf, C., de Bazelaire, C., Faivre, S., Bertheau, P., Raymond, E., Germain, S. and Janin, A. (2013) Differential Regulation of Sunitinib Targets Predicts Its TumorType-Specific Effect on Endothelial and/or Tumor Cell Apoptosis. Cancer Chemotherapy and Pharmacology, 72, 1183-1193. http://dx.doi.org/10.1007/s00280-013-2300-0

\section{List of Abbreviations}

TKI: tyrosine kinase inhibitor

VEGFR: vascular endothelial growth factor receptor

PDGFR: platelet-derived growth factor receptor

HUVEC: human umbilical vein endothelial cell 


\section{Submit or recommend next manuscript to SCIRP and we will provide best service for you:}

Accepting pre-submission inquiries through Email, Facebook, Linkedin, Twitter, etc A wide selection of journals (inclusive of 9 subjects, more than 200 journals)

Providing a 24-hour high-quality service

User-friendly online submission system

Fair and swift peer-review system

Efficient typesetting and proofreading procedure

Display of the result of downloads and visits, as well as the number of cited articles

Maximum dissemination of your research work

Submit your manuscript at: http://papersubmission.scirp.org/ 